\title{
Pelaksanaan dan Partisipasi Mahasiswa dalam Pemilihan Presiden dan Wakil Presiden BEM Universitas Negeri Padang menggunakan Sistem Elektronik Voting
}

\author{
Ikhsanur Rahman, Suryanef \\ Program Studi Pendidikan Pancasila dan Kewarganegaraan \\ Universitas Negeri Padang \\ E-mail: ikhsanur.rahman.yandra@hotmail.com
}

\section{ABSTRAK}

Penelitian ini dilatar belakangi oleh partisipasi mahasiswa dalam pemilihan presiden dan wakil presiden Badan Eksekutif Mahasiswa Universitas Negeri Padang (BEM UNP) itu rendah walaupun sudah menggunakan sistem Elektronik Voting serta kurangnya kesadaran mahasiswa akan pentingnya menggunakan hak pilih dalam pemilihan presiden dan wakil presiden BEM UNP. Tujuan dari penelitian ini adalah untuk mendeskripsikan bagaimana partisipasi mahasiswa serta faktor-faktor yang mempengaruhi rendahnya partisipasi mahasiswa dalam pelaksanaan pemilihan presiden dan wakil presiden BEM UNP dengan menggunakan sistem Elektronik Voting (E-Voting). Penilitian ini penting dilakukan karena e-voting dalam pemilihan presiden dan wakil presiden BEM UNP sudah menggunakan hak pilihnya, namun tetap saja partisipasi mahasiswa itu rendah. Jenis penelitian ini adalah kualitatif dengan metode deskriptif. Pemilihan informan menggunakan teknik purposive. Hasil penelitian ini menunjukan bahwa partisipasi mahasiswa dalam pemilihan presiden dan wakil presiden BEM UNP dengan menggunakan sistem Elektronik Voting (E-Voting) masih rendah terutama pada tahun 2019 ini yang hanya berkisar 27\% sedangkan 73\% lagi tidak menggunakan hak pilihnya. Partisipasi mahasiswa yang rendah dapat ditinjau dari beberapa faktor tertentu. Faktor-faktor yang mempengaruhi partisipasi mahasiswa ini adalah kepemimpinan, pendidikan, serta komunikasi. Faktor lain yang menurut penulis juga mempengaruhi partisipasi mahasiswa dalam pemilihan presiden dan wakil presiden BEM UNP antara lain sosialisasi, kinerja tim sukses dalam hal ini kampanye, popularitas pasangan calon, serta akses dari sistem E-Voting itu sendiri. Dapat disimpulkan bahwa partisipasi mahasiswa dalam pemilihan presiden dan wakil presiden Badan Eksekutif Mahasiswa masih tergolong rendah walaupun sudah menggunakan sistem elektronik.

Kata Kunci: partisipasi, BEM, elektronik voting

\section{ABSTRACT}

This research is backed by students ' participation in the presidential election and vice president of the State University Student Executive Board (BEMUNP) is low despite already using electronic Voting system and lack of Student awareness of the importance of using voting rights in the presidential election and vice president of BEM UNP. The purpose of this 
study is to describe how students ' participation and the factors that affect the low Student participation in the implementation of presidential election and vice president of BEM UNP by using electronic Voting system (E-Voting). This study is important because e-voting in presidential election and vice president of BEM UNP has been using the right of choice, but still why the student participation is low. This type of research is qualitative with a descriptive method. Selection of informant using purposive technique. The results of this study showed that the participation of students in the presidential election and vice president of BEM UNP using electronic E-Voting is still low especially in the year 2019 which only ranges from $27 \%$ while $77 \%$ is not Use the right of choice. Low student participation can be reviewed from certain factors. The factors influencing student participation are leadership, education, and communication. Other factors which according to the author also affect the student participation in the presidential election and vice president of BEM UNP among others are socialization, successful team performance in this namely campaign, the popularity of candidate pairs, as well as access from the system E-Voting itself. It can be concluded that the student participation in the presidential election and vice president of the student Executive Body is still relatively low despite the use of electronic systems.

Keywords : participation, student executive board, electronic voting

(c) (7) (?) This work is licensed under the Creative Commons Attribution-ShareAlike 4.0 International License. $\bigcirc 2019$ BY SA by author.

Received: Des $262019 \quad$ Revised: Jan $212020 \quad$ Accepted: Feb 62020

\section{PENDAHULUAN}

Mahasiswa merupakan kaum intelektual yang akan menjadi generasi penerus bangsa di masa yang akan datang. Dalam mengembangkan potensi yang dimilikinya, mahasiswa tidak hanya memanfaatkan hard-skill yang didapat selama kuliah didalam ruangan saja, namun dapat berhimpun dalam organisasi-organisasi kemahasiswaan yang juga merupakan sarana pembelajaran bagi mahasiswa untuk mengembangkan berbagai softskill yang dimilikinya seperti kemampuan sosial dan religius. Organisasi-organisasi kemahasiswaan yang dibentuk oleh mahasiswa merupakan miniature state yang dapat melaksanakan tugas dan fungsi layaknya sebuah negara itu sendiri. Mekanisme pemilihan dalam suatu organisasi kemahasiswaan tersebut juga menggunakan sistem yang sama yaitu sistem pemilihan secara langsung.

Pada lingkungan perguruan tinggi, pemilihan dilaksanakan dalam rangka memilih pimpinan Badan Eksekutif Mahasiswa. Pemilihan presiden dan wakil presiden BEM UNP ini dilaksanakan berdasarkan Surat Keputusan Rektor Universitas Negeri Padang No.55/ J.41/ KM/ 2004 tentang Petunjuk Teknis Organisasi Kemahasiswaan Universitas Negeri Padang. Pelaksanaan pemilihan hampir sama dengan pemilihan presiden dan wakil presiden pada umumnya yang menggunakan asas pemilihan langsung. Namun, perbedaannya adalah pada sistemnya yang lebih mengedepankan penggunaan sistem elektronik voting. 
Elektronik voting atau biasa disebut dengan e-voting merupakan suatu sistem pemungutan suara dalam pemilihan dengan menggunakan sistem digital atau sistem elektronik. Seperti yang dikemukakan oleh Rokhman (dalam Ridwan. 2016), evoting merupakan pemungutan suara dengan tahapan mulai dari pendaftaraan pemilih, pelaksanaan pemilihan, perhitungan suara dan pengiriman hasil suara dilaksanakan secara elektonik atau digital. Shalahuddin (dalam Purwati. 2015) menyebutkan bahwa e-voting merupakan sebuah proses pemungutan suara yang memanfaatkan media elektronik. Azhari (dalam Priyono. 2010) juga mengatakan bahwa e-voting merupakan penggunaan teknologi komputer pada pelaksanaan voting. Dari penjelasan di atas dapat dipahami bahwa e-voting merupakan suatu sistem pemilihan berbasis elektronik mulai dari awal pelaksanaan sampai pada penghitungan suara.

E-voting bertujuan untuk menyelenggarakan pemungutan suara dengan biaya yang hemat serta penghitungan suara yang cepat serta sistem yang aman. Inovasi pelaksanaan pemilihan umum yang dilaksanakan melalui sistem elektronik ini di lingkungan perguruan tinggi dinilai dapat memudahkan mahasiswa dalam menyalurkan hak pilihnya. Selain bisa diakses melalui internet, evoting ini juga dapat membantu mahasiswa karena mahasiswa tidak perlu datang atau melakukan pemilihan di tempat pemilihan umum (TPS) yang telah disediakan tetapi bisa dilakukan dimana saja mahasiswa tersebut berada.
Seperti beberapa hasil penelitian terdahulu yaitu penelitian oleh Risnanto (2017) menyatakan bahwa aplikasi pemungutan suara elektronik dirancang dengan sangat sederhana dan biaya yang murah untuk memudahkan peserta pemungutan suara dan pelaksanaan pemungutan suara. Penelitian oleh Arifin dan Hendro (2016) menyatakan bahwa perlunya perancangan sistem e-voting dalam pelaksanaan Pemilihan BEM di Universitas Muria Kudus agar pemilihan dapat dilakukan secara bersamaan. Kemudian penelitian oleh Widyawati dan Mulyani (2018) mengatakan bahwa pelaksanaan pemungutan suara melalui elektronik voting diharapkan dapat membantu masyarakat perantauan dalam menggunakan hak suara mereka. Dari pemaparan di atas dapat disimpulkan bahwa penelitian-penelitian terdahulu hanya terfokus pada perancangan dan pengembangan aplikasi e-voting saja untuk menyukseskan Pemilihan di daerah. Sedangkan pada penelitian ini, penulis ingin bagaimana partisipasi mahasiswa khususnya di lingkungan Universitas Negeri Padang dalam pelaksanaan pemilihan presiden dan wakil presiden Badan Eksekutif Mahasiswa yang menggunakan sistem elektronik voting (e-voting).

Pemilihan presiden dan wakil presiden BEM juga dilaksanakan di berbagai universitas, antara lain di Universitas Indonesia, Institut Teknologi Bandung, Universitas Padjajaran, Universitas Pendidikan Indonesia, Universitas Trisakti, dan Universitas Pasundan. Pemilihan presiden dan wakil presiden BEM UI misalnya, menggunakan sistem one man one vote dengan menerapkan sistem electronic voting (e-voting) 
yang terintegrasi dengan Sistem Informasi Akademik Next Generation (SIAK-NG).

Pemilihan BEM dengan sistem evoting di UNP yang dilakukan untuk memilih presiden dan wakil presiden BEM sudah dilaksanakan sejak tahun 2014 lalu. Tujuan penggunaan sistem tersebut untuk mempermudah mahasiswa UNP menggunakan hak pilihnya. Dengan adanya e-voting, diharapkan dapat mempermudah mahasiswa UNP yang sedang berada di luar lingkungan kampus agar dapat menggunakan hak pilihnya tanpa harus datang ke Tempat Pemungutan Suara (TPS) yang telah disediakan panitia penyelenggara.

Meskipun sistem e-voting ini sudah dirancang sedemikian rupa untuk dapat mempermudah mahasiswa dalam menyalurkan hak pilihnya dalam pemilihan presiden dan wakil presiden BEM UNP, kenyataannya masih banyak mahasiswa yang tidak menggunakan hak pilihnya dalam pemilihan presiden dan wakil presiden BEM di Universitas Negeri Padang. Hal ini bisa dilihat pada hasil pemilihan presiden dan wakil presiden BEM UNP yang dilaksanakan setiap tahunnya.

Tabel. 1.1

Rekapitulasi jumlah mahasiswa yang menggunakan hak pilihnya dalam pemilihan presiden dan wakil presiden BEM UNP tahun 2013-2018

\begin{tabular}{|l|l|l|l|l|}
\hline No & Tahun & $\begin{array}{l}\text { Jumlah Mahasiswa } \\
\text { yang Memilih }\end{array}$ & $\begin{array}{l}\text { Jumlah } \\
\text { Keseluruhan } \\
\text { Mahasiswa }\end{array}$ & Persentase \\
\hline 1 & 2013 & 10.818 & 30.049 & $36 \%$ \\
\hline 2 & 2014 & 5.031 & 28.527 & $21 \%$ \\
\hline 3 & 2016 & 7.375 & 26.150 & $28 \%$ \\
\hline 4 & 2017 & 10.451 & 32.905 & $31 \%$ \\
\hline 5 & 2018 & 11.416 & 34.773 & $33 \%$ \\
\hline
\end{tabular}

Sumber: Surat Kabar Kampus (SKK) Ganto dan Website dari Internet
Dari rekapitulasi data di atas dapat dilihat bahwa keikutsertaan mahasiswa dalam pemilihan presiden dan wakil presiden BEM UNP mengalami peningkatan persentase dari tahun ke tahun. Namun masih banyak juga mahasiswa yang tidak menggunakan hak pilihnya dalam pemilihan presiden dan wakil presiden BEM UNP itu sendiri walaupun sudah menggunakan sistem Elektronik Voting.

\section{METODE PENELITIAN}

Dalam penelitian ini, penulis menggunakan pendekatan penelitian kualitatif deskriptif, karena penelitian ini berusaha untuk mendeskripsikan peristiwa yang sebagaimana terjadi dilapangan. Penelitian ini berfokus pada bagaimana partisipasi mahasiswa dalam pemilihan presiden dan wakil presiden BEM UNP dengan menggunakan Elektronik Voting dan faktor-faktor yang mempengaruhi partisipasi mahasiswa dalam pemilihan presiden dan wakil presiden BEM UNP dengan menggunakan sistem E-Voting. Lokasi penelitian ini adalah di lingkungan kampus utama UNP. Informan penelitian ini adalah mahasiswa aktif di UNP. Jenis dan sumber data dalam penelitian ini adalah data primer dan data sekunder. Data primer dalam penelitian ini bersumber dari wawancara dengan mahasiswa aktif UNP.

Sedangkan data sekunder
dalam penelitian ini meliputi
rekapitulasi jumlah mahasiswa yang
menggunakan hak pilihnya dalam
pemilihan presiden dan wakil
presiden BEM UNP. Teknik
pengumpulan data diperoleh melalui
wawancara, observasi, dan studi


dokumentasi. Dalam menguji keabsahan data dalam penelitian, penulis menggunakan teknik triangulasi dengan triangulasi sumber. Kemudian data yang diperoleh akan dianalisis melalui tahap reduksi data, penyajian data, dan penarikan kesimpulan.

\section{HASIL DAN PEMBAHASAN}

a. Pelaksanaan Pemilihan Presiden dan Wakil Presiden BEM UNP dengan menggunakan Sistem Elektronik Voting.

Dalam pelaksanaan pemilihan presiden dan wakil presiden BEM UNP menggunakan sistem E-Voting, prosesnya terbagi atas beberapa tahaptahap sebagai berikut:

1) Tahap Perencanaan

Pada tahap ini, Majelis Perwakilan Mahasiswa Universitas Negeri Padang (MPM UNP) membentuk PPU atau Panitia Pemilihan Umum yang di pilih dari keanggotaan MPM UNP itu sendiri serta mahasiswa UNP yang berasal dari luar keanggotaan MPM UNP yaitu delegasi dari masing-masing HMJ dilingkungan Universitas Negeri Padang.

\section{2) Tahap Pelaksanaan}

Setelah Panitia Pemilihan Umum terbentuk, kegiatan dilanjutkan dengan Sosialisasi Pemilu yang dilakukan oleh PPU bersama dengan Panwaslu pemilihan presiden dan wakil presiden BEM UNP. Sosialisasi dilakukan di lingkungan kampus UNP dengan cara mendatangi fakultasfakultas yang ada di lingkungan UNP itu sendiri. Sosialisasi dilakukan di kampus pusat serta hampir di seluruh kampus cabang Universitas Negeri Padang.

Setelah kegiatan sosialisasi pemilu yang dilakukan oleh PPU, kini dilanjutkan dengan pendaftaran calon presiden dan wakil presiden BEM UNP. Mahasiswa yang ingin mendaftarkan diri atau orang lain, mendatangi sekretariat MPM UNP untuk mengambil formulir pendaftaran pasangan calon presiden dan wakil presiden BEM UNP. Setelah mahasiswa melakukan pendaftaran, dilanjutkan dengan kegiatan verifikasi yang terbagi atas verifikasi awal dan verifikasi akhir. Pada tahap verifikasi awal bakal pasangan calon melakukan penyerahan berkas yang ada untuk melengkapi persyaratan sebagai calon presiden dan wakil presiden BEM UNP yang sudah ditetapkan oleh MPM saat itu. Pada masa itu juga MPM memberikan waktu kepada bakal pasangan calon untuk melengkapi kekurangan dari syaratsyarat yang akan diserahkan ke MPM UNP.

Setelah itu dilanjutkan dengan tahap verifikasi akhir dimana bakal pasangan calon menyerahkan berkasberkas yang sudah dilengkapi sebelumnya. Setelah kegiatan verifikasi awal dan verifikasi akhir, kegiatan dilanjutkan dengan sidang verifikasi yang dihadiri oleh Pimpinan MPM, Pimpinan PPU dan anggotanya, pasangan calon yang menyerahkan berkas pada saat verifikasi akhir, serta tim sukses dari masing-masing pasangan calon itu sendiri. Sidang dilakukan secara tertutup sehingga hanya pimpinan MPM, pimpinan PPU dan anggotanya, pasangan calon yang menyerahkan berkas pada saat verifikasi akhir, serta tim sukses dari 
masing-masing pasangan calon yang mengetahui hasil sidang verifikasi pada saat itu. Sehingga ditetapkan nomor urut pasangan calon yang akan berlaga pada pemilihan presiden dan wakil presiden BEM UNP.

Setelah penetapan nomor urut pasangan calon dalam sidang verifikasi, kegiatan dilanjutkan dengan kampanye yang dilakukan oleh masing-masing pasangan calon dengan tim suksesnya. Kegiatan kampanye ini terbagi atas dua tahapan yaitu kampanye monologi dan kampanye dialogis. Kampanye monologis merupakan kampanye yang diinisiasi oleh pasangan calon presiden dan wakil Presiden BEM UNP yang diketahui oleh PPU dan Panwaslu pemilihan presiden dan wakil presiden BEM UNP. Dalam kampanye monologis, pasangan calon beserta tim suksesnya akan melakukan arak-arakan untuk menyampaikan visi dan misinya kepada mahasiswa Universitas Negeri Padang.

Sedangkan kampanye dialogis atau yang biasa disebut dengan Debat Pasangan Calon merupakan inisiasi dari PPU serta diawasi oleh Panwaslu. Kegiatan kampanye dialogis ini dilakukan di dua lokasi berbeda yaitu di kampus cabang Bukittinggi serta di kampus pusat UNP di air tawar Barat Padang. Debat dihadiri oleh Rektor UNP, Pembina MPM, Ketua MPM dan anggota-anggotanya, PPU, Panwaslu, serta mahasiswa Universitas Negeri Padang. Masing-masing pasangan calon akan menyampaikan serta beradu argumen terkait dengan visi dan misinya selama menjabat sebagai presiden dan wakil presiden BEM UNP nantinya. $\begin{array}{crr}\text { Setelah } & \text { kegiatan } & \text { kampanye } \\ \text { dilaksanakan, } & \text { barulah } & \text { seluruh }\end{array}$ mahasiswa UNP menggunakan hak pilihnya dengan membuka website http:/ / evoting.pkm.unp.ac.id/ baik di smartphone, di laptop maupun di TPS yang sudah disediakan oleh PPU.

3) Tahap Evaluasi

Pada tahap evaluasi pelaksanaan pemilihan presiden dan wakil presiden BEM UNP diukur dari sejauh mana keberhasilan dari pelaksanaan pemilihan itu sendiri. Berdasarkan dari temuan penelitian, pelaksanaan pemilihan presiden dan wakil presiden BEM UNP tahun 2019 ini telah berjalan dengan baik walaupun masih ada kendala-kendala yang ditemui baik itu dari perencanaan kegiatan sampai pada akhir pelaksanaan kegiatannya. Dapat disimpulkan bahwa pelaksanaan pemilihan presiden dan wakil presiden BEM UNP sudah berjalan dengan semestinya walaupun masih banyak ditemui kendala-kendala baik itu dari masa kampanye sampai pada pengumuman pasangan calon yang memperoleh suara terbanyak.

\section{b. Kendala dalam Pelaksanaan Pemilihan Presiden dan Wakil Presiden BEM UNP Menggunakan Sistem Elektronik Voting}

Penggunaan sistem elektronik dalam pemilihan merupakan hal yang tidak asing lagi di telinga kita. Namun seiring berjalannya waktu, sistem elektronik voting sudah memiliki banyak pembaharuan walaupun penerapan sistem tersebut dalam pemilihan masih dijumpai berbagai kendala. Menurut Hansen dan Mowen (dalam Selviana dan Setya: 2016), kendala dapat di kategorikan atau dikelompokkan berdasarkan asal nya 
Volume 3 No. 12020

menjadi dua macam, antara lain sebagai berikut:

\section{1) Kendala Internal}

Pada kendala internal, hal-hal yang menjadi kendala dalam pelaksanaan pemilihan presiden dan wakil presiden BEM UNP adalah pertama letak kampus Universitas Negeri Padang tidak hanya disatu tempat saja melainkan tersebar di banyak tempat yang sering disebut sebagai Kampus Pusat dan Kampus Cabang. Keberadaan beberapa kampus cabang inilah yang menyulitkan panitia untuk melakukan sosialisasi secara merata dan maksimal. Di dalam sosialisasi yang dilakukan panitia ke kampus cabang, banyak ditemukan fakta bahwa banyak mahasiswa kampus cabang menganggap bahwa pemilihan presiden dan wakil presiden BEM UNP yang menggunakan sistem elektronik voting ini merupakan suatu hal yang tidak begitu penting dan juga tidak dirasakan manfaatnya bagi mereka. Hal itu menjadi tantangan tersendiri bagi panitia penyelenggara untuk menarik minat mahasiswa kampus cabang untuk menggunakan hak pilihnya dalam pemilihan presiden dan wakil presiden BEM UNP.

Kendala internal kedua yang ditemui adalah dalam pemilihan presiden dan wakil presiden BEM UNP pada tiga tahun terakhir jumlah pasangan calon selalu dua pasangan saja. Hal tersebut secara jumlahnya hanya melibatkan mahasiswa dari 4 fakultas yang berbeda saja. Apalagi dari pasangan calon yang berlaga pada pemilihan, ada yang dari fakultas yang sama seperti pada pemilihan presiden dan wakil presiden BEM UNP tahun
2019 ini yang kedua calon dari masing masing pasangan calon berasal dari fakultas yang sama pula yaitu Fakultas Ilmu Sosial. Sehingga bagi mahasiswa fakultas yang tidak ada calon dari mereka tidak begitu peduli dengan proses pemilihan yang terjadi karena mereka tidak mengenal pasangan calon yang bersangkutan, sehingga mereka tidak terlalu memperdulikannya. Hal tersebut juga menjadi kendala bagi panitia penyelenggara pemilihan presiden dan wakil presiden BEM UNP.

Kendala internal ketiga yang ditemui adalah sikap apatisme mahasiswa yang semakin terasa sampai sekarang ini. Mahasiswa banyak yang tidak menggunakan hak pilihnya dalam pemilihan Presiden dan Wakil Presiden BEM UNP karena menurut mereka hal tersebut tidak berpengaruh pada nilai akademiknya sehingga mereka tidak begitu peduli. Kurangnya partisipasi mahasiswa untuk mengikuti kegiatan pemilihan Presiden dan Wakil Presiden BEM UNP juga dirasakan oleh Majelis Perwakilan Mahasiswa (MPM) UNP serta Panitia Pengawas Pemilu (Panwaslu) UNP.

\section{2) Kendala Eksternal}

Kendala eksternal yang ditemui berasal dari jumlah mahasiswa. Jumlah mahasiswa UNP yang sangat besar berpotensi membuat aplikasi menjadi error saat melakukan pemilihan ketika diakses secara serentak. Hal tersebut sangat di pengaruhi oleh kualitas jaringan yang digunakan mahasiswa ketika menggunakan hak pilihnya. Kendala ekternal lainnya adalah dari faktor alam seperti hujan badai, listrik mati dan lain sebagainya. Hal tersebut 
dapat mengganggu pelaksanaan pemilihan presiden dan wakil presiden BEM UNP dengan menggunakan sistem elektronik voting ini.

\section{c. Upaya untuk Mengatasi Kendala dalam Pelaksanaan Pemilihan Presiden dan Wakil Presiden BEM UNP yang Menggunakan Sistem Elektronik Voting}

Dalam rangka untuk mengatasi kendala yang ditemui pada pelaksanaan pemilihan presiden dan wakil presiden BEM UNP dengan menggunakan sistem elektronik voting ini, beberapa upaya telah dilakukan oleh berbagai bagian terkait, seperti UPT PTIK UNP dan tim admin yang sedang berupaya mengembangkan serta mengkaji sistem elektronik voting ini lebih baik lagi. Salah satu yang sedang dikembangkan adalah peralihan penggunaan username dan password portal akademik UNP ke penggunaan sistem smartcard. Hal tersebut masih dalam tahap pengembangan oleh tim admin sehingga upaya login gagal yang ditemui mahasiswa diharapkan dapat diminimalisir.

Pemilihan presiden dan wakil presiden BEM UNP dengan menggunakan sistem elektronik voting ini harus disosialisasikan serta dikomunikasikan oleh pihak panitia penyelenggara pemilihan kepada mahasiswa UNP secara keseluruhan dan merata agar nantinya dapat mengurangi banyaknya mahasiswa yang tidak mengetahui pelaksanaan pemilu serta dapat menggunakan hak pilihnya dalam pemilihan.

Dalam rangka meningkatkan partisipasi mahasiswa dalam pemilihan Presiden dan Wakil
Presiden BEM UNP, panitia penyelenggara pemilihan telah berupaya menyediakan Tempat Pemungutan Suara atau TPS di masing-masing fakultas yang mana terdapat dua laptop yang dapat digunakan mahasiswa untuk melakukan pemilihan. Upaya tersebut bertujuan untuk memudahkan mahasiswa dalam menggunakan hak pilihnya dalam pelaksanaan pemilihan serta salah satu upaya yang dilakukan panitia penyelenggara pemilihan untuk menyemarakkan pelaksanaan pemilihan presiden dan wakil presiden Badan Eksekutif Mahasiswa Universitas Negeri Padang.

\section{d. Faktor-Faktor yang Mempengaruhi Rendahnya Partisipasi Mahasiswa dalam Pemilihan Presiden dan Wakil Presiden BEM UNP Menggunakan Sistem Elektronik Voting}

Partisipasi merupakan keikutsertaan atau berperan serta atau ikut ambil bagian dalam suatu kegiatan tertentu. Menurut Verayanti (dalam Trisna: 2018) partisipasi politik merupakan kegiatan seseorang untuk ikut serta dalam kegiatan politik dengan memilih pemimpin negara baik secara langsung maupun secara tidak langsung. Bentuk-bentuk dari partisipasi politik adalah antara lain memberikan hak suara dalam pemilihan umum, mengadakan hubungan dengan pejabat pemerintahan, menghadiri rapat umum, ataupun menjadi bagian dari partai politik (Budiardjo, 2008). Jadi dapat disimpulkan bahwa partisipasi dalam hal ini adalah keikutsertaan seseorang dalam memilih seorang pemimpin.

Berdasarkan dari kajian teori yang penulis gunakan dalam BAB II 
sebelumnya, ada beberapa faktor yang mempengaruhi tingkat partisipasi seseorang menurut Mikkelsen B (dalam Carissa Agustia. 2017) antara lain kepemimpinan, tingkat pendidikan dan komunikasi. Faktor kepemimpinan sangat berperan penting dalam mempengaruhi partisipasi seseorang. Semakin kuat sikap kepemimpinan yang dimiliki seseorang tersebut, maka akan semakin mudah pula seseorang tersebut dalam menggerakkan massa untuk ikut berpartisipasi dalam suatu program atau kegiatan tertentu.

Pendidikan juga dapat mempengaruhi tingkat partisipasi seseorang. Semakin tinggi tingkat pendidikan seseorang, maka semakin tinggi pula pengetahuan mereka akan pentingnya berpartisipasi dalam suatu kegiatan atau program. Komunikasi dapat mempengaruhi tingkat partisipasi mahasiswa dalam pemilihan presiden dan wakil presiden BEM UNP. Semakin hebat pasangan calon tertentu dalam mengkomunikasikan visi dan misinya, maka akan mudah membuat orang lain tertarik untuk ikut serta dalam pelaksanaan pemilihan Presiden dan Wakil Presiden BEM UNP itu sendiri.

Ada juga beberapa faktor yang menurut penulis mempengaruhi partisipasi mahasiswa dalam pemilihan Presiden dan Wakil Presiden BEM UNP dengan menggunakan sistem Elektronik Voting (E-Voting). Faktor-faktor tersebut antara lain sosialisasi, kinerja tim sukses, popularitas pasangan calon, dan aksesibiltas e-voting.

Sosialisasi merupakan suatu proses penanaman atau transfer kebiasaan atau nilai dan aturan dari suatu generasi kegenerasi lainnya dalam sebuah kelompok atau masyarakat. Sosialisasi meliputi pamflet, brosur, banner, spanduk, baliho, stiker, dan lain sebagainya. Sosialisasi berfungsi agar mahasiswa dapat mengetahui kegiatan yang akan dilaksanakan, sehingga menciptakan keinginan untuk berpartisipasi. Dalam kegiatan pemilihan Presiden dan Wakil Presiden BEM UNP, sosialisasi yang dilakukan sebelum pelaksanaan sudah baik, sudah hampir merata ke setiap fakultas di UNP sendiri. Namun dalam hasilnya, masih banyak mahasiswa yang tidak menggunakan hak pilihnya dalam pemilihan presiden dan wakil presiden BEM UNP.

Kinerja tim sukses dalam hal ini adalah kampanye. Kampanye merupakan serangkaian kegiatan atau tindakan yang bersifat komunikasi yang terencana dengan tujuan untuk menciptakan efek tertentu pada sejumlah orang atau kelompok yang dilakukan secara terus menerus pada kurun waktu tertentu. Kampanye sendiri berfungsi untuk memperkenalkan pasangan calon kepada mahasiswa baik itu visi misi nya maupun latar belakangnya, sehingga diharapkan dapat menciptakan keinginan untuk ikut berpartisipasi. Dalam pelaksanaan kegiatan pemilihan Presiden dan Wakil Presiden BEM UNP, tim sukses dari setiap paslon sudah baik dalam menyampaikan visi dan misi paslonnya, namun dilihat dari hasilnya masih banyak juga mahasiswa yang tidak menggunakan hak pilihnya.

Kemudian popularitas calon merupakan poin yang cukup 
signifikan dalam pelaksanaan pemilihan pemimpin terutama pada pelaksanaan pemilihan Presiden dan Wakil Presiden BEM UNP dimana kriteria dan kinerja dari pasangan calon terpilih akan langsung mempengaruhi calon pemilih khususnya mahasiswa itu sendiri.

E-Voting merupakan suatu sistem pemilihan yang dimulai dari pendaftaran, pemilihan, pemungutan suara, penghitungan suara, sampai pengiriman hasil suara dilakukan secara elektronik atau digital. Sistem Elektronik Voting itu sendiri digunakan pada pemilihan Presiden dan Wakil Presiden BEM UNP sampai sekarang. Seharusnya sistem Elektronik Voting dalam pemilihan Presiden dan Wakil Presiden BEM UNP dapat meningkatkan partisipasi mahasiswa dalam pemilihan itu sendiri karena dengan adanya sistem ini mahasiswa dapat menggunakan hak pilihnya tanpa harus datang ketempat pemungutan suara yang telah disediakan panitia pelaksana pemilihan. Namun kenyataannya, masih banyak mahasiswa yang tidak menggunakan hak pilihnya dalam pemilihan tersebut.

\section{KESIMPULAN}

Pelaksanaan pemilihan presiden dan wakil presiden BEM UNP memiliki beberapa tahapan, antara lain: Tahap perencanaan yaitu pembentukan panitia; Tahap pelaksanaan yaitu sosialisasi pemilu yang dilakukan oleh PPU dan Panwaslu, pendaftaran bakal pasangan calon presiden dan wakil presiden BEM UNP, verifikasi berkas yang terdiri atas verifikasi awal dan verifikasi akhir, sidang verifikasi berkas, dan penetapan nomor urut pasangan calon presiden dan wakil presiden BEM UNP, masa kampanye yang terbagi atas kampanye monologis dan kampanye dialogis atau debat pasangan calon, evoting pemilihan presiden dan wakil presiden BEM UNP; Tahap evaluasi: yaitu evaluasi dari awal kegiatan sampai pada pengumuman hasil pemilihan presiden dan wakil presiden BEM UNP.

Kendala yang ditemui dalam pelaksanaan pelaksanaan pemilihan presiden dan wakil presiden BEM UNP dengan menggunakan sistem Elektronik Voting terbagi atas kendala internal dan kendala eksternal. Kendala internal yang ditemui antara lain sosialisasi pemilu yang kurang merata, pasangan calon yang berlaga selalu dua paslon saja, sikap apatisme mahasiswa yang memprihatinkan, ada berbagai pelanggaran-pelanggaran yang ditemui baik itu dalam masa kampanye, maupun dalam hari pemilihan presiden dan wakil presiden BEM UNP. Sedangkan kendala eksternal yang ditemui antara lain aplikasi yang sering error dikarenakan mahasiswa menggunakan di waktu yang sama, serta faktor alam lainnya. Upaya yang dilakukan untuk mengatasi kendala dalam pelaksanaan pemilihan presiden dan wakil presiden BEM UNP dengan menggunakan sistem Elektronik Voting antara lain pengembangan dan pengkajian sistem Elektronik Voting kearah yang lebih baik lagi yang dilakukan oleh pihakpihak terkait.

Partisipasi mahasiswa dalam pemilihan presiden dan wakil BEM UNP dengan menggunakan sistem elektronik Voting masih rendah dilihat dari hasil pemilihan presiden dan 
wakil presiden BEM UNP yang kurang dari $27 \%$ dan sisanya banyak yang tidak menggunakan hak pilihnya. Hal tersebut tentu dipengaruhi oleh beberapa faktor tertentu. Partisipasi mahasiswa dalam pemilihan presiden dan wakil presiden BEM UNP di pengaruhi oleh beberapa faktor. Adapun dari Faktor tersebut adalah dari segi kepemimpinan, pendidikan serta komunikasi; dan juga ada beberapa faktor yang menurut penulis juga berpengaruh dari segi sosialisasi, kinerja tim sukses, popularitas pasangan calon, serta akses dari sistem Elektronik Voting itu sendiri.

\section{DAFTAR PUSTAKA}

Agustia, Carissa. 2017. Pengaruh Partisipasi Aktif terhadap Akademik Mahasiswa dalam kelompok Pelayan Tuhan di gereja. Yogyakarta: Universitas Sanata Dharma.

Arifin, Muhammad, Hendy Hendro Sajono. 2016. Analisa dan Perancangan Sistem E-Voting Pemilu Raya BEM (PEMIRABEM) di Universitas Muria Kudus. Seminar Nasional Sistem Informasi Indonesia, 1 Nopember 2016

Budiardjo, Miriam. 2008. Dasar-Dasar Ilmu Politik: Edisi Revisi. Jakarta: Gramedia Pustaka Utama.

http:// evoting.pkm.unp.ac.id/

Larasati, Selviana Putri, Setya Haksama. 2016. Penerapan theory of Constraint pada kepuasan kerja Karyawan Ruman Sakit Mata Undaan Surabaya. Jurnal Administrasi Kesehatan Indonesia Volume 4 Nomor 2 Juli-Desember 2016
Priyoni, Edi. Fereshti Nurdiana Dihan. 2010. E-Voting: Urgensi, Transparansi dan Akuntabilitas. Yogyakarta: Seminar nasional Informatika 2010 ISSN: 1979-2328

Purwati, Nani. 2015. Perancangan Sistem E-Voting untuk Pemilihan Kepala Daerah (Pilkada). Jurnal Bianglala Informatika Vol. 3 No. 1 Maret 2015

Ridwan, Muhammad. Dkk. 2016. Rancang Bangun E-Voting dengan Menggunakan Keamanan Algoritma Rivest Shamir Adleman (RSA) Berbasis Web (Studi Kasus: Pemilihan Ketua BEM FMIPA). Jurnal Informatika Mulawarman Vol. 11, No. 2 September 2016.

Risnanto, Slamet. 2017. Aplikasi Pemungutan Suara Elektronik /E-Voting Menggunakan Teknologi Short Message Service dan At Command. Jurnal Teknik Informatika Vol.10 No.1

Surat Keputusan Rektor Universitas Negeri Padang No.55/ J.41/ KM/ 2004 tentang Petunjuk Teknis Organisasi Kemahasiswaan Universitas Negeri Padang

Trisna, Vika. 2018. Faktor-Faktor Penyebab Tingginya Partisipasi Politik Mahasiswa pada Pemilu Badan Eksekutif Mahasiswa Periode 2018-2019 (Studi pada Fakultas Ilmu Sosial Universitas Negeri Padang. Padang: Journal of Civic Education Vol 2 Nomor 3. ISSN: 2622-237X 
36 | pelaksanaan dan partisipasi..

Undang-undang Republik Indonesia Nomor 12 Tahun 2012 Tentang Pendidikan Tinggi

Widiyawati, Bekti. Mulyani. 2018. Pengembangan Electrinic Voting (E-Voting) sebagai Alat Bantu Pemungutan Suara bagi Masyarakat Perantauan. Surakarta: STMIK Duta Bangsa. 